JOURNAL OF PUBLIC HEALTH FOR TROPICAL AND COASTAL REGION

(JPHTCR)

Journal homepage: http:/ejournal2.undip.ac.id/index.php/jphtr/index

ISSN : 2597-438

\title{
Microplastic Pollution in Waters and its Impact on Health and Environment in Indonesia: A Review
}

\author{
Sarinah Basri K ${ }^{1,2 *}$,Basri K³., Eko Maulana Syaputra1, Sri Handayani4,5 \\ ${ }^{1}$ Department of Public Health, Faculty of Public Health, Universitas Wiralodra, Indramayu, Indonesia \\ 2Department of Environmental Health, Faculty of Public Health, Universitas Hasanuddin, Makassar, \\ Indonesia \\ ${ }^{3}$ Department of Technology and Vocational Education FKIP Universitas Nusa Cendana, Kupang, \\ Indonesia \\ ${ }^{4}$ Department of Epidemiology, Faculty of Public Health, Universitas Hasanuddin, Makassar, Indonesia \\ ${ }^{5}$ STIK Tamalatea Makassar, Indonesia \\ ${ }^{*}$ Corresponding Author. Email: b_sarinah@unwir.ac.id
}

\begin{abstract}
Introduction: Microplastics have become a pollution problem that has received worldwide attention. Microplastics in the water impact the environment and health, especially in Indonesia, which is the second largest plastic waste contributor in the world. This literature study aims to determine the distribution of microplastics pollution in waters and its impact on health and the environment in Indonesia.

Methods : The literature search on papers from 2010-2021 through Google Scholar, Pubmed, ScienceDirect, and ProQuest, with the keywords of 'Microplastics', 'Indonesia', 'aquatic', 'environment' found 477 articles. Then, after exclusion of duplicate articles, and other inclusion criteria, the final review was done on 42 articles. PRISMA guidelines was used for reviewing procedure.

Results: Most microplastic research was conducted in Java Island, which is dominated by rivers and beaches. Based on the source, microplastics came from domestic waste, tourism and fishing activities. The most common forms found were black and blue fibers from fishing lines, nets and clothing fibers of various sizes. The type of polymer identified is polyethylene plastic. Microplastics impacted the tourist destinations, marine ecosystems through the food chain and also humans who consume seafood.

Conclusion: Microplastics are found in the Indonesian marine environment. Humans can consume seafood contaminated with microplastics, which will have an impact on health. Therefore, health risk assessment should be done to provide information for taking environmental management efforts.
\end{abstract}

Keywords: Microplastics, Aquatic, Environment, health

Article History: Received: $12^{\text {th }}$ April 2021, Revised: $9^{\text {th }}$ June 2021, Accepted: $2^{\text {nd }}$ August 2021

\section{Introduction}

Microplastics (MPs) are a growing pollution problem which recently expressed as a tremendous contaminant of all environmental components. ${ }^{1,2}$ Then, microplastics received the attention of scientists, politics, media, the general public and various circles. ${ }^{3-15}$

Asia is the region with the fastest growing waste production in the world. Five countries are responsible for more than $50 \%$ of all plastic waste in the oceans, all of 
which are in the Asian region which is China, Vietnam, the Philippines, Thailand, and Indonesia. ${ }^{16}$ Currently, plastic waste in Indonesia can be called an emergency because Indonesia is the second contributor to plastic waste in the world. ${ }^{17}$ In 2019, Indonesia produced around 67.8 million tonnes and this will continue to grow as the population grows. ${ }^{18}$

The source of plastic waste comes from residential areas and various industries which use plastic to package their products. ${ }^{19}$ Apart from its very large source, plastic waste is dumped into the oceans, thus posing a serious threat to marine life. ${ }^{20}$ Microplastics can pose a risk to marine organisms and ecological processes. This is also presumed to pose a risk to seafood security. ${ }^{21}$ From various studies, more than 690 marine species have been affected by plastic waste with tiny plastic particles observed in the digestive tracts of organisms of various trophic levels. ${ }^{22}$ Of the 192 countries in the world, only $22.9 \%$ (44) countries that have researched microplastics and their impact on organisms mostly target fish (38\%). ${ }^{23}$

Microplastics are often detected in the digestive tract of aquatic organisms. ${ }^{24}$ In an African study, it was found that $35 \%$ of fish samples ingested plastic particles analyzed in the digestive tract. ${ }^{5}$ Microplastics can also physically stick to the gills and skin of fish. ${ }^{25}$ Other studies have revealed that excreted fish (whole fish excluding offal and gills) contained higher levels of microplastics than cut organs (offal and gills), highlighting that evisceration did not necessarily eliminate the risk of consuming microplastics by consumers. ${ }^{26}$

Seafood is consumed by human worldwide, so the presence of microplastics has the potential to pose a food safety risk. ${ }^{27}$ However, knowledge about the adverse effects on human health due to the consumption of marine organisms containing microplastics is still very limited. ${ }^{28}$ But based on the literature, the potential toxicity of particle on human health can be focused on gastrointestinal toxicity, liver toxicity, neurotoxicity, and reproductive toxicity, which involves oxidation stress mechanisms, inflammatory reactions, and metabolic disorders. ${ }^{29}$ Other toxicity produced is inflammation due to persistent microplastic properties, as well as its unique nature such as hydrophobicity and chemical composition, and it is suspected to have an accumulative effect depending on dosage. Microplastic has shown that cytotoxic effects induced in T98G and Hela cells (human brains and epithelial cells). ${ }^{30}$ Polystyrene microplastic with a diameter of $460 \mathrm{~nm}$ and $1 \mu \mathrm{m}$ can affect erythrocytes. ${ }^{31}$ This literature study aimed to determine the distribution of microplastics pollution in waters and its impact on health and the environment in Indonesia.

\section{Methods}

\section{Study Selection}

The article search included Indonesian and English language articles with open access. This search was conducted through Google Scholar, Pubmed, ScienceDirect, and ProQuest.

\section{Inclusion/Exclusion Criteria}

The database search criteria utilized the keywords of 'microplastics', 'Indonesian', 'aquatic' and 'environment'. The articles accessed were articles from 2010 to 2021. The search found 477 articles. Data were extracted manually by research title, year of publication and research method.

The inclusion criteria for article searches were: 1) full text availability; 2) targeting microplastics in the aquatic environment. The exclusion criteria were: 1) theses, books, review articles, final assignments, papers, outline, and baseline; 2) double publication. Criteria for data storage in publications were: 1) location; 2) specific location; 3) source and type of plastic; 4) method; 5) shape; 6) polymer type, and 7) environmental and human impacts.

Data Extraction

This literature review referred to the Preferred Reporting Items for Systematic Reviews (PRISMA) guidelines. It can be seen in Figure 1. 




Figure 1. Flow chart Literature

Results

Study Location

Forty-two articles were included in this review. The location of this study is presen -ted in Figure 2. The locations of microplastics studies were mostly on Java Island. As can be seen in Figure 2, the least number of studies were

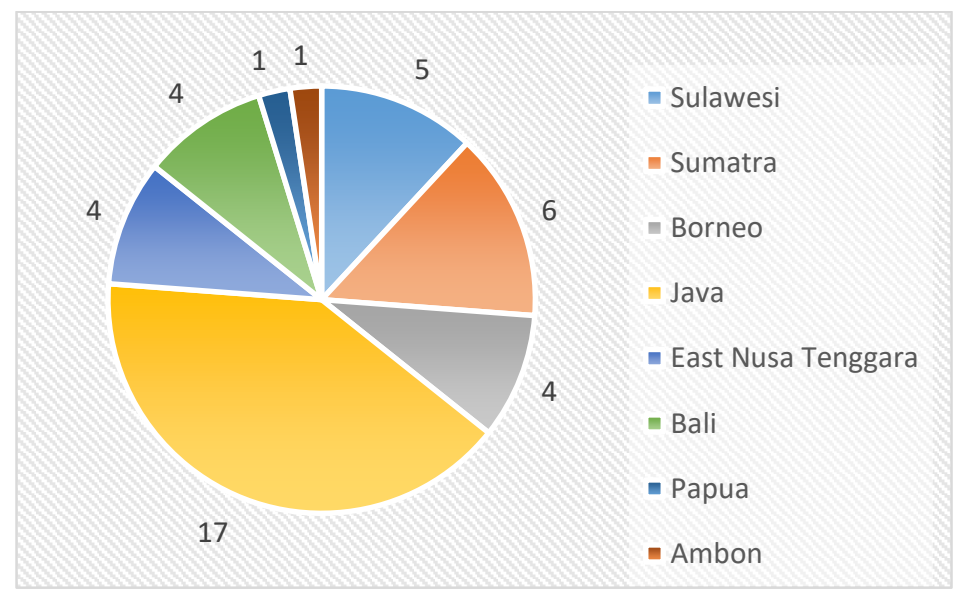

Figure 2. The Location of microplastic presence 
done in Papua and Ambon. The high level of population concentration in Java compared to other islands motivates the researcher to relate the microplastics in the environment with anthropogenic factors. ${ }^{32}$

The microplastic studies were mostly done in Java Island. A study showed that wastes were accumulated through Bengawan Solo River, which in turn due to the currents were carried into Java Sea. The microplastic in the currents then accumulates on the water of Banyuurip Village, East Java. The river estuary and sea is affected by the currents with a speed between $0,1-0,2 \mathrm{~m} / \mathrm{s}^{33}$ In Surabaya, the majority of waste were came from domestic and industrial sources. ${ }^{34}$ People living in the area of $500 \mathrm{~m}$ radius from Surabaya River, dumps their domestic waste to the river body ${ }^{35}$ and about 10 industrial waste outlets, dump their waste water to the river $^{34}$. Other studies in East Java, one on Pantai Utara, East Java, founded that the high level of human activity is the catalyst of a high amount of plastic waste disposed into the sea. ${ }^{36}$ The beach along Tuban Regency also has a high potential for microplastic contamination, with the higher concentration on the river estuary. Lack of proper microplastic management (incomplete burning, unplanned burning and dumping) can be the possible cause of microplastic transportation and their relative abundance around the beaches and river estuary area. Myriads of human activity directly affects areas as a waste disposal areas. ${ }^{37}$ Plastic waste accumulation, indirectly, affects fishing capabilities, sea ecosystem, tourism sectors and the health of people around the coastline of Pasuruan Regency. ${ }^{38}$ People's activity directly and indirectly causes an impact to the water environment around the coast of Mangunharjo Village, Tugu District, Central Java. ${ }^{39}$ Kendal River in Central Java flows from the land to the sea with a length of $9.5 \mathrm{~km}$, with $40.56 \mathrm{~km}^{2}$ size of River Flow Area (DAS) and $216 \mathrm{~m}^{3} / \mathrm{sec}$ river water debit, has a potential to carry microplastic. ${ }^{40}$ Human activity can contribute to microplastic contamination, such as on Ayah Beach Kebumen which is also a tourist destination and closed to a fishmonger. Daily plastic waste in Kebumen on 2018 was 9.09 tonnes or approximately $24 \%$ of the total managed waster. ${ }^{41}$ Still on Central Java, there are 5 main rivers in Yogyakarta which ferries plastic waste from densely populated area to the sea in southern Yogyakarta, for example, is on Baron Beach, Gunungkidul Regency. ${ }^{42}$ On the western area of Java, which is the Banten Gulf, plastic waste are spread through water flow and food chain and then reaching the island chain of Seribu. ${ }^{43}$

The beach and rivers were the most specific places of studies. Specific locations which highlights Beach and Rivers such as: Surabaya River ${ }^{34}$, Kendal River $^{40}$, Beringin River ${ }^{39}$, Siak River ${ }^{44}$, Sei Sikambing River ${ }^{45}$, Banyuurip River Estuary $^{33}$, Lakatong River estuary ${ }^{46}$, river estuary and Kartini Beach area ${ }^{47}$, Mangunharjo Beach ${ }^{39}$, Tuban Regency ${ }^{37}$, Ayah Beach Kebumen ${ }^{41}$, Baron Beach ${ }^{42}$, Lekok Beach, Pasir Panjang Beach, Watuprapat Beach and Kapasan at Pasuruan Beach ${ }^{38}$, Indah Kapuk Beach ${ }^{48}$, Doublesix Beach, Kuta Beach, Melasti Beach, Mengiat and Tanjung Benoa Beach, which is in the tourist destination of Badung Regency Beach ${ }^{49}$, Desa Air Kuning Beach, Kubu Tambahan Beach, Serangan Beach, Kusamba Beach, Jembrana Area Lebih and Soka Beach. ${ }^{50}$

The source of microplastic waste as shown on Table 1 is dominated by domestic waste or from household activities. Indonesia is known as a dense populated country which certainly affects the abundance of microplastics. ${ }^{42,65}$ The total plastic waste generation in Indonesia reaches 5.4 tons per year, which is $14 \%$ of the total amount of household waste. ${ }^{66}$ 
Table 1. Sources of Microplastics Waste and Types of Waste Produced

\begin{tabular}{|c|c|c|}
\hline Sources & Types of Waste & Reference \\
\hline Tourism activities & Seating thread & (49) \\
\hline $\begin{array}{l}\text { Fishing activities and domestic } \\
\text { wastes }\end{array}$ & $\begin{array}{l}\text { Synthetic materials in clothing as well as fishing gear such } \\
\text { as fishing rods or nets }\end{array}$ & (51) \\
\hline Domestic wastes & Remnants of fishing gear and plastic packaging & (52) \\
\hline $\begin{array}{l}\text { Domestic wastes and } \\
\text { anthropogenic activities }\end{array}$ & $\begin{array}{l}\text { Bottles, plastic bags, and PVC pipe pieces, fishing boat } \\
\text { and fishing gear wastes such as fishing nets and fishing } \\
\text { line, and also food packaging }\end{array}$ & (33) \\
\hline $\begin{array}{l}\text { Industrial area and domestic } \\
\text { wastes }\end{array}$ & $\begin{array}{l}\text { Plastic bags, plastic containers, or toys and fiber from } \\
\text { fishing gear }\end{array}$ & $(40)$ \\
\hline $\begin{array}{l}\text { Domestic wastes, fisherman } \\
\text { activities and tourism activities }\end{array}$ & $\begin{array}{l}\text { Plastic bags and plastic bottles, mica plastic packaging, } \\
\text { fishing line or packing nets }\end{array}$ & $(47)$ \\
\hline $\begin{array}{l}\text { Domestic wastes, beach for } \\
\text { tourism, Fish Auction }\end{array}$ & $\begin{array}{l}\text { Plastic fiber, clothes, household appliances, plastic bottle } \\
\text { pieces, mica, PVC pipes, plastic bag fragmentation and } \\
\text { another packaging }\end{array}$ & $(41)$ \\
\hline Domestic and fishery wastes & $\begin{array}{l}\text { Food packaging, plastic bags, detergent packaging, } \\
\text { fishing gear, plastic cups and bottle caps }\end{array}$ & (38) \\
\hline $\begin{array}{l}\text { Shops or food stalls and } \\
\text { domestic wastes }\end{array}$ & $\begin{array}{l}\text { Plastic bags, food packaging, plastic bottles, straws, } \\
\text { plastic cups and other plastic waste, degradation of fishing } \\
\text { gear in the form of ropes, clothing to plastic sacks }\end{array}$ & (53) \\
\hline $\begin{array}{l}\text { Domestic waste of tourists and } \\
\text { other anthropogenic activities }\end{array}$ & $\begin{array}{l}\text { The effect of clothing materials, cigarette butts, rigging } \\
\text { from fishing activities, drink bottles, discarded jars, fast } \\
\text { food packaging and office wastes }\end{array}$ & $(54)$ \\
\hline Fishery and tourism activities & $\begin{array}{l}\text { Domestic plastic wastes, fishing lines, fishing nets, } \\
\text { productions, washing and textiles }\end{array}$ & $(55)$ \\
\hline $\begin{array}{l}\text { Domestic wastes, shops and } \\
\text { food stalls, ports and fisherman } \\
\text { activities }\end{array}$ & $\begin{array}{l}\text { Plastic bags either big or small, rice wrappers, ready-to- } \\
\text { eat food packaging and plastic bottles, plastic bags for the } \\
\text { fishermen to wrap the fish, food and ice blocks, and fishing } \\
\text { gear used by fishermen which comes from ropes }\end{array}$ & $(56)$ \\
\hline $\begin{array}{l}\text { Domestic wastes, the existence } \\
\text { of public and fish markets, ports, } \\
\text { fisheries, shops and tourism } \\
\text { activities }\end{array}$ & $\begin{array}{l}\text { Clothing threads, remaining washing water, plastic bags } \\
\text { and Styrofoam as fish storage }\end{array}$ & $(57)$ \\
\hline $\begin{array}{l}\text { Domestic wastes and tourism } \\
\text { activities }\end{array}$ & $\begin{array}{l}\text { Drink bottles, the remains of wasted jars, gallon pieces and } \\
\text { small pieces of PVC pipes, clothes and ropes }\end{array}$ & $(58)$ \\
\hline Domestic wastes & $\begin{array}{l}\text { Boat ropes, synthetic fabrics which come off as a result of } \\
\text { the washing process, fishing nets, industrial raw materials, } \\
\text { household appliances, plastic bags designed to degrade } \\
\text { in the environment, or due to weathering of plastic } \\
\text { products }\end{array}$ & (59) \\
\hline $\begin{array}{l}\text { Domestic and textile industry } \\
\text { wastes }\end{array}$ & Synthetic clothing and laundry activities & $(60)$ \\
\hline Domestic wastes & Plastic bottles & $(61)$ \\
\hline Fishing spots & $\begin{array}{l}\text { Fishing gear such as nets and fishing rods as well as those } \\
\text { made from synthetic materials }\end{array}$ & (62) \\
\hline $\begin{array}{l}\text { Domestic wastes, fishing, laying } \\
\text { fishing nets, sorting out plastic } \\
\text { wastes, and loading and } \\
\text { unloading goods, fishing boats, } \\
\text { and fishing gears }\end{array}$ & $\begin{array}{l}\text { Plastic wastes and packaging bottles, sacks, clothing } \\
\text { fibers, fishing lines, nets, and mooring ropes }\end{array}$ & $(44)$ \\
\hline $\begin{array}{l}\text { Fishing boats and big ships } \\
\text { Ports, fishing, mining, trade, } \\
\text { tourism activities and domestic } \\
\text { wastes }\end{array}$ & $\begin{array}{l}\text { Fishing nets, plastic bottle ropes and plastic bags } \\
\text { Drink bottles, discarded jars, rice wrappers, fast food } \\
\text { packaging and office waste disposal }\end{array}$ & $\begin{array}{l}(63) \\
(64)\end{array}$ \\
\hline
\end{tabular}

Apart from household activities, the presence of microplastics is also influenced by tourism and fishing activities. Tourism activities conducted between tourists and 
tourism actors, directly and indirectly, can cause waste generation every day. A study from the United Nations Environment Program (UNEP) stated that tourists on average produce six times more waste when they were on vacation. ${ }^{67}$ Fishing activities also affect the amount of plastic in the waters and on the other hand, fishermen will also be affected. The presence of plastic can hinder boat travel (waste of fuel), disturb aesthetics in tourist areas (loss to tourism), and interfere with health. 68

\section{Shape, Size, and Colours of Microplastics}

Shows the existence of 8 forms of microplastic (Fiber, Fragment, Film, Foam, Filament, Pellet, Granule, and Microbead) and each article did not only discuss and find one form of microplastic. The most microplastics form found was fibers of different sizes, which has been mentioned in 34 articles.

Fibre form of microplastic commonly comes from river or estuary areas due to the anthropogenic influences. ${ }^{57}$ Fibre were found to be of the highest concentration in comparison with the three other type of plastic waste in Lekok Beach and Panjang Beach. The high level of fishing activity in both of these beaches is the reason for the fibres' abundance. ${ }^{38}$ The microplastic comes from the usage of fish catching apparatus such as fishing rods and degraded fishing nets. ${ }^{49}$ The most dominant type of microplastic that were identified inside the Lemuru Protolan fish were fibre. ${ }^{51}$ In the other study, fibres were found on the digestive tract of Swanggi fish. It was assumed that it originates from the fishing catching apparatus and nets that were used. ${ }^{36}$ On sea urchins, the average weight on fibre microplastic were found to be $0.0058 \mathrm{~g}$ per individual, which is assumed due to fisherman activities using fishing nets. ${ }^{69}$ Other than on biotas, fibres are also a type of microplastic which were most commonly found on sediments. ${ }^{55}$ Fibre also comes from boat ropes that are no longer used by fishermen or ones that experience friction and then break down into very small plastic particles which are then carried away by inflows into the waters. ${ }^{39}$ High amount of fibre type can also be suspected from the rest of the cloth of seat cover of bean bag which are directly placed on the beach ${ }^{49}$ or from the clothing fibre of domestic waste. ${ }^{44}$

Microplastics come in various forms, sizes and colors. Microplastics are usually defined as plastic waste which degrades and breaks down into small plastic particles $\leq 5 \mathrm{~mm} .{ }^{36}$ The size of microplastics can be divided into two which is large $(1-\leq 5 \mathrm{~mm})$ and small $(1 \mu \mathrm{m}-\leq 1000 \mu \mathrm{m}) .^{70}$ In all of the studies, the found smallest microplastic size was $28 \mu \mathrm{m}$ and the largest size was 5 $\mathrm{mm}$.

Various colors of plastic material are made with the addition of dyes. ${ }^{34}$ The discovery of microplastics with various colors can be seen in Figure 3 . The dominant colors are black (17\%), blue $(17 \%)$ and red (15\%). The microplastics found during high and low tides are dominated by black, white, red, blue and green colored fibers. ${ }^{57}$ Fiber is shaped like a thread with various colors such as blue, red and black. ${ }^{39}$ Another study stated that the fibers found had a morphology similar to fishing nets or fibers with dark blue, light blue and red colors. ${ }^{55}$

The color of microplastics on the surface of the river water, the middle depth and the bottom of the Surabaya river was found to be blue and black and red. ${ }^{34}$ The color of microplastics at all stations, namely the river estuary were also found to be black, red, blue, pink. ${ }^{47}$ The dominant colors of microplastics found in fish samples were black (38 particles), red (11 particles), blue (6 particles). ${ }^{50}$ Black microplastic has a high ability to absorb pollutants. ${ }^{71}$

In all microplastic studies the highest amount found was black. Black color can indicate the amount of contaminants absorbed in microplastics and other organic particles. Black microplastics also have a high ability to absorb pollutants, which also affects the texture of microplastics. ${ }^{58}$ The black color indicates the types of polystyrene and polypropylene and is thought to also contain pollutants such as PAHs and adsorbed PCBs. ${ }^{41}$

Staining in plastics can pose a potential eco-toxicological risk to aquatic biota due to the release of chemical compounds. ${ }^{34}$ The color of the microplastic 


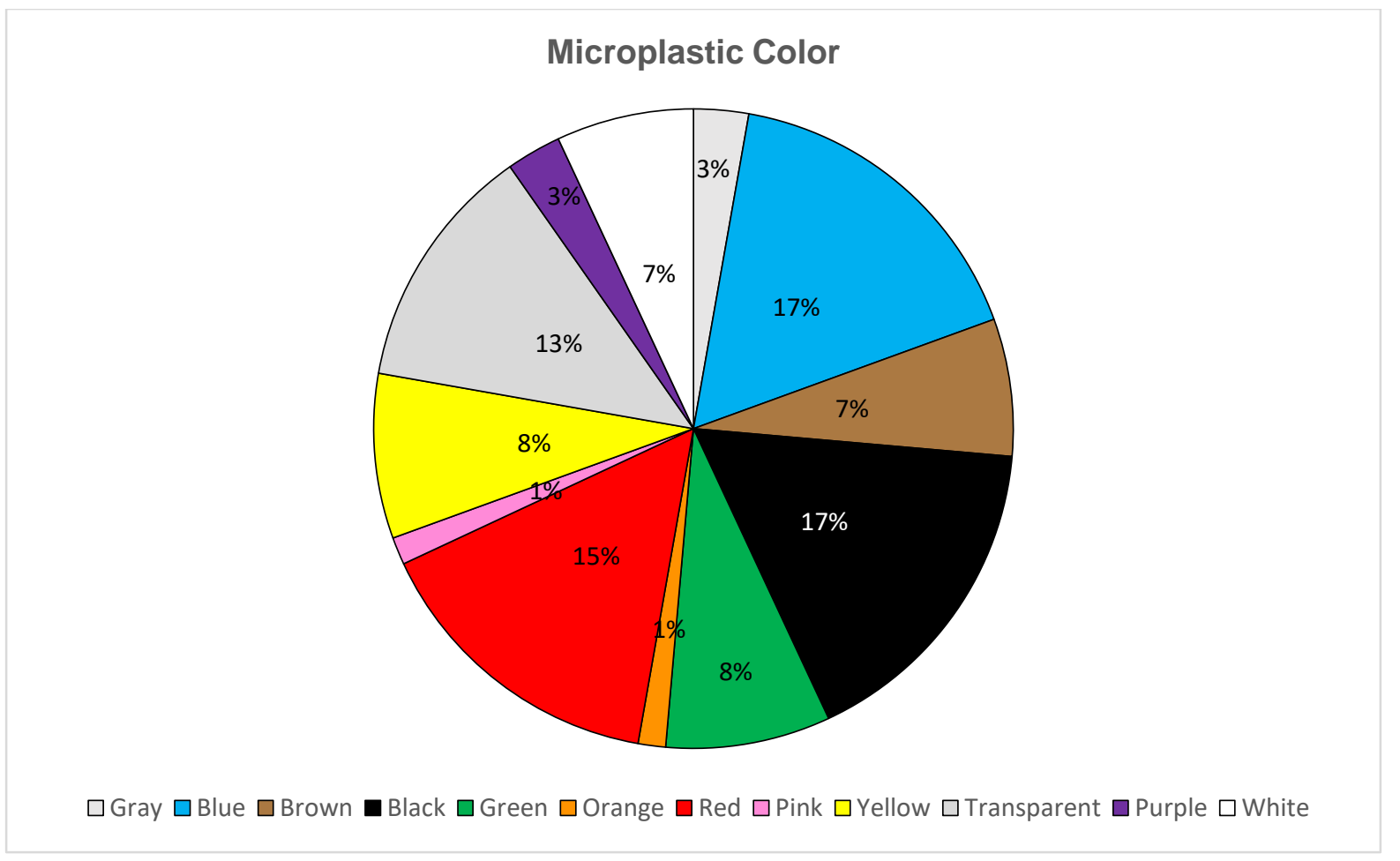

Figure 3. Microplastic Color

particles in the environment increases the potential consumption of the biota because of their similarity to natural prey. ${ }^{48}$

\section{Types of Microplastic Polymers}

To identify the type of polymer, all of the studies used Fourier transform infrared spectrophotometry (FT-IR) test. FT-IR is the most popular technique and is often used to identify polymer types from microplastics. ${ }^{49}$

The test results with FT-IR are in the form of graphs with specific wavelength values. This wavelength value shows the functional group of a compound. ${ }^{39}$

Based on the results, the type of polymer found was dominated by polyethylene and polypropylene. The estimation of the types of polyethylene and polypropylene polymers in the sample was indicated by the presence of a wavelength peak was in the range of $2,935-2,915 \mathrm{~cm}^{-1}$ which was interpreted the presence of $\mathrm{CH}$ stretch bonds. ${ }^{40}$ The peak results from the FTIR test of Sei Sikambing River water samples from the three locations contained bonds with the following wavelengths: $2913.47 \mathrm{~cm}^{-1}, 2846.07 \mathrm{~cm}^{-1}, 1463.13 \mathrm{~cm}^{-1}$,
$1371.86 \mathrm{~cm}^{-1}, \quad 1028.23 \mathrm{~cm}^{-1}$. These wavelengths are close to the standard wavelengths for polyethylene and polypropylene. ${ }^{45}$ The low density polymers (low density polyethylene, polyethylene and polypropylene) of microplastic in the study were not only found on the surface, but also in the depths of other rivers. This condition can be affected by biofouling. Biofouling gradually forms a biofilm on the surface area of the microplastic. ${ }^{34}$ Polypropylene can come from broken polypropylene-based chairs due to the abundance of such chairs along the coast. ${ }^{49}$ Most of the microplastics are found with a dark color that can be used as an initial identification of polyethylene polymers which have low density which are abundant in surface waters. Polyethylene is the main ingredient in plastic waste bags and containers. ${ }^{58}$ Polyethylene plastic can increase the concentration of $\mathrm{CO}_{2}$, decrease the concentration of $\mathrm{O}_{2}$ which slow down the damage process and the shelf life of the product. ${ }^{72}$ 
Impact of Microplastics for the Environment and Food Chain

Microplastic research in Indonesia focuses more on water and sediment. Studies globally state that microplastics have also been detected in water bodies and sediments on seven continents and four oceans. ${ }^{73}$ Microplastics have the potential to disrupt the food chain if they accumulate in water areas. ${ }^{52}$ Microplastics are present in all aquatic ecosystems and can be digested by a wide variety of organisms through consumption. ${ }^{74-75}$ Sea fish are widely used as food for human consumption. ${ }^{76} \quad$ Therefore, many researchers have focused their studies on microplastics in fish, as can be seen in Table 2.

Table 2. Microplastic Objects

\begin{tabular}{clclc}
\hline No & Object & $\begin{array}{c}\text { Total } \\
\text { article }\end{array}$ & Shape & $\begin{array}{c}\text { Total } \\
\text { article }\end{array}$ \\
\hline 1 & Water & 14 & Fiber & 34 \\
2 & Sediment & 16 & Fragment & 32 \\
3 & Fish & 9 & Film & 30 \\
4 & Shellfish & 3 & Foam & 5 \\
5 & Snail & 1 & Filament & 2 \\
6 & Mangrove Crab & 1 & Pellet & 5 \\
7 & Sea Urchins & 1 & Granule & 3 \\
8 & Macrozoobenthos & 1 & Microbead & 2 \\
\hline
\end{tabular}

\section{Discussion}

The large amount of plastic waste that is disposed of has an impact on the development of tourism which is currently being intensively carried out by the government. Several tourist destinations have been affected. ${ }^{77}$ Microplastics are more dangerous because they contain chemical compounds. For example, research on the coast of Cilacap, Indonesia, stated that the presence of highly toxic hydrophobic compounds had been confirmed in marine plastic waste. Thus, plastic waste can pose a threat to marine ecosystems, with the potential to release these POPs (persistent organic pollutants) into distant seawater or aquatic animal organisms, after ingestion. ${ }^{78}$

Microplastics can harm marine organisms and even reach humans through the food chain/web. ${ }^{79}$ The consumption of microphractic-containing fish may cause carcinogenic and non carcinogenic risk in humans, based on the intake rate. Both non-carcinogenic or carcinogenic risks indicate the strong relation with the concentration (C) of microplastic in fish, intake rate $(R)$, shelf frequency (FE), exposure duration, and weight (WE) of the respondents. ${ }^{80}$ Based on the results of the study, microplastics were found in all feces of samples of pregnant women in the working area of Puskesmas Pattingalloang and Jumpandang Baru, Makassar. Microplastics were found from thirty stool samples ranging from 5-21 microplastics with the types of fibers, fragments, and films due to fish consumption. ${ }^{81}$

In the human body, after swallowing foods containing microplastic, it interact with the mucus layer of the digestive tract. Then, microplastic particles combine and cross the mucosal layer and in contact with epithelial cells. Microplastic is then transferred to lymphatic and circulatory systems, and through this system, microplastic reaches and builds up in organs such as the liver, the kidneys, the spleen, the heart and the brain which in turn have an effect on human health. ${ }^{25}$ Alternative consumption of microparticles can cause changes of chromosomes which causes infertility, obesity, and cancer. ${ }^{82}$ Ingestion of microplastics can cause local inflammation and cancer due to immune cell response, especially in individuals with metabolic disorders and poor cleansing mechanisms. $^{83} \quad$ Polyvinyl chloride microplastics that enters into the digestive organs and human blood circulation systems can absorb and bind serum albumin, destroy the molecular structure and function of proteins, transfer to each 
organ through the blood, and further cause more serious in vivo damage. ${ }^{84}$

Research on the adverse effects of microplastics on the environment and health in Indonesia is still limited. Therefore, it is necessary to conduct more in-depth research as well as efforts to reduce its impact. Research conducted in Tempode, Salama Village, Manggarai Regency, East Nusa Tenggara, to reduce the dangers and impacts of microplastics showed that it is necessary to introduce the management of coastal areas as part of the ecosystem through outreach activities to coastal communities. With the socialization, the public's understanding on the concept of marine waste, microplastics, and ecosystems has increased by $76 \%{ }^{79}$ Apart from the efforts to manage the aquatic environment, it is important to estimate the intake of microplastics in humans. Estimates on the global average, humans can ingest $0.1-5 \mathrm{~g}$ of microplastic each week via various exposure routes. ${ }^{85}$ Considering the potential risk of contamination, the edible parts of fish and food sizes that are safe for adults is $300 \mathrm{~g} /$ week and for children is $50 \mathrm{~g} /$ week. $^{86}$

\section{Conclusion}

Microplastics are very dangerous for the environment and humans. Humans are exposed to microplastics through food chain contamination. Therefore, analysis and assessment of the potential health risks has to be done to provide information and make the right decision. Efforts to overcome these problems must be carried out, especially in reducing the accumulation of plastic waste in the ocean environment and strict regulation for the use of plastic products.

\section{Author Contribution}

SBK contributes to conceptualization, writing the sections of "the presence of microplastic in Indonesia by general and specific locations," "the source and type of plastic" and "the microplastic forms." SH and EMS contribute to the sections of "the microplastic identification methods" and "the environmental and health impacts on humans due to microplastic" BK contributes to the sections of "data analysis method", prepared the tables and figures, editing the language. All authors read the manuscript and approve the final manuscript.

\section{Ethics Approval \\ Not applicable}

\section{References}

1. Dodson GZ, Shotorban AK, Hatcher PG, Waggoner DC, Ghosal S, Noffke $\mathrm{N}$. Microplastic fragment and fiber contamination of beach sediments from selected sites in Virginia and North Carolina, USA. Mar Pollut Bull. 2020;151:110869. Available from: https://doi.org/10.1016/j.marpolbul.2 $\underline{019.110869}$

2. Campanale C, Savino I, Pojar I, Massarelli C, Uricchio VF. A practical overview of methodologies for sampling and analysis of microplastics in riverine environments. Sustain. 2020;12(17). https://doi.org/10.3390/su12176755

3. Barboza LGA, Lopes C, Oliveira P, Bessa F, Otero V, Henriques B, et al. Microplastics in wild fish from North East Atlantic Ocean and its potential for causing neurotoxic effects, lipid oxidative damage, and human health risks associated with ingestion exposure. Sci Total Environ. 2020;717:134625. Available from: https://doi.org/10.1016/j.scitotenv.20 19.134625

4. Barboza LGA, Cunha SC, Monteiro C, Fernandes JO, Guilhermino L. Bisphenol A and its analogs in muscle and liver of fish from the North East Atlantic Ocean in relation to microplastic contamination. Exposure and risk to human consumers. J Hazard Mater. 2020;393:122419. Available from: https://doi.org/10.1016/j.jhazmat.202 0.122419

5. Merga LB, Redondo-Hasselerharm PE, Van den Brink PJ, Koelmans AA. Distribution of microplastic and small macroplastic particles across four fish species and sediment in an African lake. Sci Total Environ. 2020;741:140527. Available from: https://doi.org/10.1016/i.scitotenv.20 $\underline{20.140527}$ 
6. Ahmad M, Li J-L, Wang P-D, Hozzein WN, Li W-J. Environmental perspectives of microplastic pollution in the aquatic environment: a review. Mar Life Sci Technol. 2020;(0123456789). Available from: https://doi.org/10.1007/s42995-02000056-w

7. Yang Y, Liu W, Zhang Z, Grossart HP, Gadd GM. Microplastics provide new microbial niches in aquatic environments. Appl Microbiol Biotechnol. 2020;104(15):6501-11. https://doi.org/10.1007/s00253-02010704-X

8. Piehl S, Atwood EC, Bochow M, Imhof HK, Franke J, Siegert F, et al. Can Water Constituents Be Used as Proxy to Map Microplastic Dispersal Within Transitional and Coastal Waters? Front Environ Sci. 2020;8. https://doi.org/10.3389/fenvs.2020.0 $\underline{0092}$

9. Guo JJ, Huang XP, Xiang L, Wang YZ, Li YW, Li H, et al. Source, migration and toxicology of microplastics in soil. Environ Int. 2020;137:105263. Available from: https://doi.org/10.1016/j.envint.2019. 105263

10. Donoso JM, Rios-Touma B. Microplastics in tropical Andean rivers: A perspective from a highly populated Ecuadorian basin without wastewater treatment. Heliyon. 2020;6(7):e04302. Available from: https://doi.org/10.1016/i.heliyon.202 $0 . \mathrm{e} 04302$

11. Davarpanah E, Guilhermino L. Are gold nanoparticles and microplastics mixtures more toxic to the marine microalgae Tetraselmis chuii than the substances individually? Ecotoxicol Environ Saf. 2019;181:60-8. Available from: https://doi.org/10.1016/j.ecoenv.201 9.05.078

12. Hahladakis JN. Delineating the global plastic marine litter challenge: clarifying the misconceptions. Environ Monit Assess. 2020;192(5). https://doi.org/10.1007/s10661-0208202-9

13. McNeish RE, Kim LH, Barrett HA, Mason SA, Kelly JJ, Hoellein TJ. Microplastic in riverine fish is connected to species traits. Sci Rep. 2018;8(1):1-12. Available from: http://dx.doi.org/10.1038/s41598018-29980-9

14. Cowger W, Booth AM, Hamilton BM, Thaysen C, Primpke S, Munno K, et al. Reporting Guidelines to Increase the Reproducibility and Comparability of Research on Microplastics. Appl Spectrosc. 2020;74(9):1066-77. https://doi.org/10.1177/00037028209 30292

15. Jiang $Y$, Zhao $Y$, Wang $X$, Yang $F$, Chen $\mathrm{M}$, Wang J. Characterization of microplastics in the surface seawater of the South Yellow Sea as affected by season. Sci Total Environ. 2020;724:138375. Available from: https://doi.org/10.1016/j.scitotenv.20 20.138375

16. World Bank Group. Hotspot Sampah Laut Indonesia. Public Discl Auth. 2018;1-49. Available from: http://documents.worldbank.org/cura ted/en/642751527664372193/pdf/12 6686-INDONESIA-29-5-2018-14-345-SynthesisFullReportAPRILIND.pdf

17. Kementerian Keuangan Republik Indonesia. Bumi Dalam Kantong Plastik. Media Keuangan 2019;XIV(144):1-30.

18. Kementerian Lingkungan Hidup dan Kehutanan Indonesia. KLHK: Indonesia Memasuki Era Baru Pengelolaan Sampah. 2020. Available from: https://www.menlhk.go.id/site/single post/2753

19. Putra HP, Yuriandala Y. Studi Pemanfaatan Sampah Plastik Menjadi Produk dan Jasa Kreatif. J Sains \&Teknologi Lingkungan 2010;2(1):21-31.

https://doi.org/10.20885/jstl.vol2.iss1 .art3

20. Vikas Madhav N, Gopinath KP, Krishnan A, Rajendran N, Krishnan A. A critical review on various trophic transfer routes of microplastics in the context of the Indian coastal ecosystem. Watershed Ecology and the Environment. 2020;2:25-41. Available from: https://doi.org/10.1016/j.wsee.2020. $\underline{08.001}$ 
21. Walkinshaw C, Lindeque PK, Thompson R, Tolhurst T, Cole M. Microplastics and seafood: lower trophic organisms at highest risk of contamination. Ecotoxicol Environ Saf. 2020;190:110066. Available from:

https://doi.org/10.1016/i.ecoenv.201 9.110066

22. Carbery M, O'Connor W, Palanisami T. Trophic Transfer of Microplastics and Mixed Contaminants in the Marine Food Web and Implications for Human Health. Environ Int. 2018;115:400-9.

https://doi.org/10.1016/i.envint.2018. 03.007

23. Ajith $\mathrm{N}$, Arumugam S, Parthasarathy S, Manupoori S, Janakiraman S. Global distribution of microplastics and its impact on marine environment-a review. Environ Sci Pollut Res. 2020;27(21):25970-86. https://doi.org/10.1007/s11356-02009015-5

24. Roc S, Frie C, Brinker A. Uptake routes of microplastics in fishes: practical and theoretical approaches to test existing theories. Sci Rep. 2020;1-12.

25. Rao BM. Review Microplastics in the aquatic environment : implications for post-harvest fish quality. Indian J Fish. 2019;66(1):142-52.

26. Karami A, Golieskardi A, Ho Y Bin, Larat V, Salamatinia B. Microplastics in eviscerated flesh and excised organs of dried fish. Sci Rep. 2017;7(1):1-9. Available from: http://dx.doi.org/10.1038/s41598017-05828-6

27. Hara J, Frias J, Nash R. Quantification of Microplastic Ingestion by the Decapod Crustacean Nephrops norvegicus from Irish Waters. Mar Pollut Bull. 2020;152:110905. Available from: https://doi.org/10.1016/j.marpolbul.2 020.110905

28. Barboza LGA, Dick Vethaak A, Lavorante BRBO, Lundebye AK, Guilhermino L. Marine microplastic debris: An emerging issue for food security, food safety and human health. Mar Pollut Bull. 2018;133:336-48. Available from: https://doi.org/10.1016/j.marpolbul.2 018.05 .047

29. Chang X, Xue Y, Li J, Zou L, Tang M. Potential health impact of environmental micro- and nanoplastics pollution. J Appl Toxicol. 2020;40(1):4-15.

30. Campanale C, Massarelli C, Savino I, Locaputo V, Uricchio VF. A Detailed Review Study on Potential Effects of Microplastics and Additives of Concern on Human Health. Int J Environ Res Public Health. 2020;17(4).

https://doi.org/10.3390/ijerph170412 12

31. Hwang J, Choi D, Han S, Jung SY, Choi J, Hong J. Potential toxicity of polystyrene microplastic particles. Sci Rep. 2020;10(1):1-12.

32. Alam FC, Rachmawati M. Perkembangan Penelitian Mikroplastik di Indonesia. J Presipitasi. 2020;17(3):344-52.

33. Ayuingtyas WC, Yona D, Julinda SH, Iranawati F. Kelimpahan Mikroplastik Pada Perairan di Banyuurip, Gresik, Jawa Timur. J Fish Mar Res. 2019;15.

http://dx.doi.org/10.21776/ub.jfmr.20 19.003.01.5

34. Lestari $\mathrm{P}$, Trihadiningrum $\mathrm{Y}$, Wijaya BA, Yunus KA, Firdaus $M$. Distribution of microplastics in Surabaya River, Indonesia. Sci Total Environ. 2020;726:138560. Available from:

https://doi.org/10.1016/i.scitotenv.20 20.138560

35. Firdaus $\mathrm{M}$, Trihadiningrum $\mathrm{Y}$, Lestari P. Microplastic Pollution in the Sediment of Jagir Estuary, Surabaya City, Indonesia. Mar Pollut Bull. 2020;150:110790. Available from: https://doi.org/10.1016/j.marpolbul.2 019.110790

36. Labibah W, Triajie $\mathrm{H}$. Keberadaan Mikroplastik pada Ikan Swanggi (Priacanthus Tayenus), Sedimen dan Air Laut di Perairan Pesisir Brondong, Kabupaten Lamongan. Juv IIm Kelaut dan Perikan. 2020;1(3):351-8.

https://doi.org/10.21107/juvenil.v1i3. 8563 
37. Joesidawati MI. Pencemaran Mikroplastik di Sepanjang Pantai Kabupaten Tuban. Pros Semin Nas Has Penelit dan Pengabdi Kpd Masy III. 2018.

38. Yona D, Di Prikah FA, As'adi MA. Identifikasi dan Perbandingan Kelimpahan Sampah Plastik Berdasarkan Ukuran pada Sedimen di Beberapa Pantai Kabupaten Pasuruan, Jawa Timur. J Ilmu Lingkung. 2020;18(2):375-83. https://doi.org/10.14710/iil.18.2.375383

39. Laila QN, Purnomo PW, Jati OE. Kelimpahan Mikroplastik Pada Sedimen Di Desa Mangunharjo, Kecamatan Tugu, Kota Semarang. J Pasir Laut. 2020;4(1):16-21.

40. Hanif $\mathrm{KH}$, Suprijanto J, Pratikto I, Kendal K, Regency K. Identifikasi Mikroplastik di Muara Sungai Kendal , Kabupaten Kendal. J Mar Res. 2021;10(1):1-6.

41. Ridlo A, Ario R, Al Ayyub AM, Supriyantini E, Sedjati S. Mikroplastik pada Kedalaman Sedimen yang Berbeda di Pantai Ayah Kebumen Jawa Tengah. J Kelaut Trop. 2020;23(3):325-32.

https://doi.org/10.14710/jkt.v23i3.74 24

42. Suwartiningsih N, Setyowati I, Astuti R. Microplastics in Pelagic and Demersal Fishes of Pantai Baron, Yogyakarta, Indonesia. J Biodjati. 2020;5(1):33-49.

43. Patria MP, Santoso CA, Tsabita N. Microplastic ingestion by periwinkle snail littoraria scabra and mangrove crab metopograpsus quadridentata in Pramuka Island, Jakarta Bay, Indonesia. Sains Malaysiana. 2020;49(9):2151-8.

https://doi.org/10.17576/ism-20204909-13

44. Ismi $\mathrm{H}$, Amalia AR, Sari N, Gesriantuti N, Badrun Y. Dampak Mikroplastik terhadap Makrozoobentos; Suatu Ancaman bagi Biota di Sungai Siak, Pekanbaru. Pros Sains Tekes. 2019;1(2015):92-104.

45. Hasibuan $\mathrm{NH}$, Suryati I, Leonardo $\mathrm{R}$, Risky A, Ageng P, Addauwiyah R. Analisa Jenis, Bentuk Dan
Kelimpahan Mikroplastik Di Sungai Sei Sikambing Medan. J Sains dan Teknol J Keilmuan dan Apl Teknol Ind. 2020;20(2):108. http://dx.doi.org/10.36275/stsp.v20i2 .270

46. Saputri DFI, Daud A, Syah R, Birawida AB, Amqam $H$, Russeng SS. Microplastic Depuration on Asaphis Detlorata. Int J Pap Adv Sci Rev. 2020;1(2):37-46. https://doi.org/10.47667/ijpasr.v1i2.4 4

47. Azzizah P, Ridlo A, Suryono CA, Kelautan DI, Perikanan F, Diponegoro U. Mikroplastik pada Sedimen di Pantai Kartini Kabupaten Jepara , Jawa Tengah. J Mar Res. 2020;9(3):326-32.

48. Hastuti AR, Lumbanbatu DTF, Wardiatno $\mathrm{Y}$. The presence of microplastics in the digestive tract of commercial fishes off pantai Indah Kapuk coast, Jakarta, Indonesia. Biodiversitas. 2019;20(5):1233-42.

49. Mauludy MS, Yunanto A, Yona D. Microplastic Abundances in the Sediment of Coastal Beaches in Badung, Bali. J Perikan Univ Gadjah Mada. 2019;21(2):73. https://doi.org/10.22146/jfs.45871

50. Tobing SJBL, Hendrawan IG, Faiqoh E. Karakteristik Mikroplastik pada Ikan Laut Konsumsi yang didaratkan di Bali. J Mar Res Technol. 2020;3(2):102.

51. Yudhantari $\mathrm{CI}$, Hendrawan IG, Ria Puspitha NLP. Kandungan Mikroplastik pada Saluran Pencernaan Ikan Lemuru Protolan (Sardinella Lemuru) Hasil Tangkapan di Selat Bali. J Mar Res Technol. 2019;2(2):48.

https://doi.org/10.24843/JMRT.2019. v02.i02.p10

52. Hafidh D, Restu IW, Made N. Kajian Kelimpahan Mikroplastik di Perairan Teluk Benoa Provinsi Bali. Curr Trends Aquat Sci. 2018;88:80-8.

53. Adisaputra MW. Kandungan mikroplastik pada Ikan Bawis (Siganus Canaliculatus) dan Ikan Kembung (Rastrelliger Kanagurta) di Perairan Bontang. J IIm Biosmart. 2021;1:1-11. 
54. Mirad A, Yoswaty D, Riau MU, Riau MU. Identification Microplastic Waste in Seawater and The Digestive Organs of Senangin Fish (E. tetradactylum). Asian J Aquat Sci. 2020;3:248-59.

55. Simamora CSL, Warsidah W, Nurdiansyah SI. Identifikasi dan Kepadatan Mikroplastik pada Sedimen di Mempawah Mangrove Park (MMP) Kabupaten Mempawah, Kalimantan Barat. J Laut Khatulistiwa. 2020;2(3):96.

56. Dewi IS, Aditya A, Ramadhan I. Distribusi mikroplastik pada sedimen di Muara Badak , Kabupaten Kutai Kartanegara. Depik. 2015;4(3):12131.

https://doi.org/10.13170/depik.4.3.28 88

57. Kapo FA, Toruan LNL, Paulus CA. Permukaan Air Di Perairan Teluk Kupang. J Bahari Papadak. 2020;1(1):10-21.

58. Hiwari $H$, Purba NP, Ihsan $Y N$, Yuliadi LPS, Mulyani PG. Kondisi sampah mikroplastik di permukaan air laut sekitar Kupang dan Rote, Provinsi Nusa Tenggara Timur. Pros Sem Nas Masy Biodiv Indon. 2019;5:165-71.

59. Tuhumury NC. Identifikasi Keberadaan dan Jenis Mikroplastik pada Kerang Darah (Anadara Granosa ) di Perairan Tanjung Tiram , Teluk Ambon (Identification of Existance and Type of Microplastics in Cockle at Tanjung Tiram Waters, Ambon Bay). J Trit Vol. 2020;16:1-7. https://doi.org/10.30598/TRITONvol1 6issue1page1-7

60. Ramadhanty NR, Suwarno P, Nasional K, Pertahanan U. Pesisir dan Produk Garam di Provinsi Sulawesi Barat. J Educ Dev Inst. 2020;8(4):48-53.

61. Layn AA, Emiyarti, Ira. Distribution Microplastic at Sediment in the Kendari Bay. Sapa Laut. 2020;5(2):115-22.

62. Amin B, Febriani IS, Nurrachmi I, Fauzi M. Microplastics in Gastrointestinal Track of Some Commercial Fishes from Bengkalis Waters, Riau Province Indonesia. J Phys Conf Ser Pap. 2020.
63. Islami MD, Siregar YI. Distribution of Microplastic at Sediments in the Coast of Bungus Bay Padang West Sumatera Province. J Coast Ocean Sci. 2020;1(1):7-15.

64. Suriyanto S, Amin B, SN. Distribution Of Microplastics In Sea Water On The West Coast Of Karimun Island, Kepulauan Riau Province. Berk Perikan Terubuk. 2020;(2011).

65. Yumni Z, Yunita D. Identifikasi Cemaran Mikroplastik pada Ikan Tongkol (Euthynnus affinis C) dan Dencis (Sardinella lemuru) di TPI Lampulo , Banda Aceh. J Ilm Mhs Pertan. 2020;5(1):316-20. https://doi.org/10.17969/jimfp.v5i1.1 $\underline{3808}$

66. Widiyatmoko $\mathrm{H}$, Purwaningrum $\mathrm{P}$, Putri Arum PF. Analisis Karakteristik Sampah Plastik di Permukiman Kecamatan Tebet dan Alternatif Pengolahannya. Indones J Urban Environ Technol. 2016;7(1):24. http://dx.doi.org/10.25105/urbanenvir otech.v7i1.713

67. Qodriyatun SN. Sampah Plastik: Dampaknya Terhadap Pariwisata dan Solusi. Info Singkat, Pus Penelit Badan Keahlian DPR RI. 2018;10(23):13-8.

68. Sukib S, Mutiah M, Siahaan J, Supriadi S. Meningkatkan Kesadaran Bahaya Sampah Laut Melalui Pendampingan pada Masyarakat Lokasi Wisata Pantai Kuranji. J Pengabdi Magister Pendidik IPA. 2020;2(2).

https://doi.org/10.29303/ipmpi.v2i2.3 $\underline{43}$

69. Lolodo D, Nugraha WA. Mikroplastik Pada Bulu Babi dari Rataan Terumbu Pulau Gili Labak Sumenep. J Kelaut Indones J Mar Sci Technol. 2020;12(2):112-22.

https://doi.org/10.21107/jk.v12i2.626 $\underline{7}$

70. Frias J, Pagter E, Nash R, O'Connor I, Carretero O, Filgueiras A, et al. Standardised protocol for monitoring microplastics in sediments. JPIOceans BASEMAN Proj. 2018;33.

71. Wahdani, A., Yaqin, K., Rukminasari, N., Inaku, D. F., \& Fachruddin L. Konsentrasi Mikroplastik pada Kerang Manila Venerupis 
Philippinarum di Perairan Maccini Baji, Kecamatan Labakkang, Kabupaten Pangkajen Kepulauan, Sulawesi Selatan. Maspari J Mar Sci Res. 2020;12(2):1-14. https://doi.org/10.36706/maspari.v12 i2.12809

72. Saragih H, Dharma I, Astawa I. Pengaruh Ketebalan Plastik Polyethylene Densitas Rendah Terhadap Umur Simpan Bawang Daun (Allium Fistulosum L.). E-Jurnal Agroekoteknologi Trop (Journal Trop Agroecotechnology). 2016;5(4):36373.

73. Yu Q, Hu X, Yang B, Zhang G, Wang $J$, Ling W. Distribution, abundance and risks of microplastics in the environment. Chemosphere. 2020;249:126059. Available from: https://doi.org/10.1016/j.chemospher e.2020.126059

74. Naidoo T, Rajkaran A, Sershen. Impacts of plastic debris on biota and implications for human health: A South African perspective. S Afr J Sci. 2020;116(5-6):1-9. https://doi.org/10.17159/sajs.2020/7 693

75. Pannetier P, Morin B, Le Bihanic F, Dubreil L, Clérandeau C, Chouvellon $F$, et al. Environmental samples of microplastics induce significant toxic effects in fish larvae. Environ Int. 2020;134:105047. Available from: https://doi.org/10.1016/i.envint.2019. 105047

76. Barboza LGA, Vieira LR, Branco V, Figueiredo N, Carvalho F, Carvalho $\mathrm{C}$, et al. Microplastics cause neurotoxicity, oxidative damage and energy-related changes and interact with the bioaccumulation of mercury in the European seabass, Dicentrarchus labrax (Linnaeus, 1758). Aquat Toxicol. 2018;195:4957. Available from: https://doi.org/10.1016/j.aquatox.201 7.12.008

77. Wikan N R. Dampak Pencemaran Air Laut Akibat Sampah Kelestaraian Laut Di Indonesia. 2018;1-13. Available from: https://www.academia.edu/

78. Bouhroum R, Boulkamh A, Asia L, Lebarillier S, Halle A Ter, Syakti AD, et al. Concentrations and fingerprints of PAHs and PCBs adsorbed onto marine plastic debris from the Indonesian Cilacap coast and the North Atlantic gyre. Reg Stud Mar Sci. 2019;29:100611. Available from: https://doi.org/10.1016/i.rsma.2019.1 00611

79. Mulu M, Hudin R, Yohanes W. Dasor VT. Marine Debris dan Mikroplastik: Upaya Mencegah Bahaya dan dampaknya di Tempode, Salama Village, Manggarai Regency, NTT. Radang Tana J Pengabdi Kpd Masy. 2020;3(2):79-84.

https://doi.org/10.36928/jrt.v3i2.404

80. Daud A, Birawida AB, Amqam $\mathrm{H}$. Risk Analysis of Microplastic in Fish (Nemiptus Japonicas \& Rastrelliger Sp.) in Communities in the Coast Area of Tamasaju, Galesong Takalar. Med Leg Updat. 2021;21(2):196203.

https://doi.org/10.37506/mlu.v21i2.2 673

81. AR Ervina Septami, Amqam $H$, Tadjuddin Chalid SM, Daud A, Ishak $\mathrm{H}$, . S. Microplastic Identification in the Faeces of Pregnant Women. Saudi J Biomed Res. 2020;5(11):299-302.

82. Sharma S, Chatterjee S. Microplastic pollution, a threat to marine ecosystem and human health: a short review. Environ Sci Pollut Res. 2017;24(27):21530-47.

https://doi.org/10.1007/s11356-0179910-8

83. Enyoh CE, Verla AW, Verla EN, Ibe FC, Amaobi CE. Airborne microplastics: a review study on method for analysis, occurrence, movement and risks. Environ Monit Assess. 2019;191(11). https://doi.org/10.1007/s10661-0197842-0

84. Ju $P$, Zhang $Y$, Zheng $Y$, Gao $F$, Jiang $\mathrm{F}$, Li J, et al. Probing the toxic interactions between polyvinyl chloride microplastics and Human Serum Albumin by multispectroscopic techniques. Sci Total Environ. 2020;734:139219. Available from: https://doi.org/10.1016/j.scitotenv.20 20.139219 
85. Senathirajah K, Attwood S, Bhagwat G, Carbery M, Wilson S, Palanisami $\mathrm{T}$. Estimation of the mass of microplastics ingested - A pivotal first step towards human health risk assessment. J Hazard Mater. 2021;404:124004. Available from: https://doi.org/10.1016/i.jhazmat.202 0.124004
86. Akhbarizadeh $R$, Moore $F$, Keshavarzi B. Investigating a probable relationship between microplastics and potentially toxic elements in fish muscles from northeast of Persian Gulf. Environ Pollut. 2018;232:154-63. Available from:

http://dx.doi.org/10.1016/i.envpol.20 17.09 .028 